\title{
KAPASITAS SAMBUNGAN BALOK-KOLOM LAMINATED VENEER LUMBER (LVL) KAYU SENGON
}

\begin{abstract}
Jl. Ir. Sutami 36 A, Surakarta 57126 e-mail : muttaqinmuhammad92@gmail.com

The existence of wood lately more rare and the price is soaring. One alternative to solve the problem is to use Laminated Veneer Lumber (LVL) engineering wood products. This study aims to determine the LVL beam-column connection capacity with the experimental method. The connection is determined by the shape of square columns and the III-shaped beam with the bolt cone tool expected to be a rigid connection. The test is carried out by adding the load at the end of the joint to determine the deflection that occurs at the end of the beam. From the test results obtained the connection capacity beam LVL column sengon wood is 18,9; 19.9; and $17.9 \mathrm{~N} / \mathrm{mm} 2$. The comparison of test and analysis values is quite distant because the expected connection to a rigid connection is not successful. This comparison difference is caused by the non-precision bolt bole making, so it is necessary to make a better sample in order to get the rigid connection as expected.
\end{abstract}

Achmad Basuki ${ }^{1)}$, Agus Supriyadi ${ }^{2)}$, Muhammad Muttaqin ${ }^{3)}$

1),2) Pengajar Program Studi Teknik Sipil Universitas Sebelas Maret

3) Mahasiswa Program Studi Teknik Sipil Universitas Sebelas Maret

Keyword: Laminated Veneer Lumber, beam-column joint, beam-column joint capacity

\begin{abstract}
Abstrak
Keberadaan kayu belakangan ini semakin langka dan harganya semakin melambung tinggi. Salah satu alternatif untuk mengatasi masalah tersebut adalah menggunakan produk kayu rekayasa Laminated Veneer Lumber (LVL). Penelitian ini bertujuan untuk mengetahui kapasitas sambungan balok-kolom LVL dengan metode eksperimental. Sambungan ditentukan dengan bentuk kolom persegi dan balok berbentuk III dengan alat sambung baut yang diharapkan menjadi sambungan kaku (rigid connection). Pengujian dilakukan dengan penambahan beban pada ujung sambungan untuk mengetahui lendutan yang terjadi pada ujung balok. Dari hasil pengujian didapat kapasitas sambungan balok kolom LVL kayu sengon berturut-turut adalah 18,9; 19,9; dan $17,9 \mathrm{~N} / \mathrm{mm}^{2}$. Perbandingan nilai pengujian dan analisis cukup jauh disebabkan karena sambungan yang diharapkan menjadi sambungan kaku tidak berhasil. Selisih perbandingan ini disebabkan karena pembuatan lubang baut yang tidak presisi, sehingga perlu dibuat sampel yang lebih bagus lagi agar bisa didapatkan sambungan kaku sesuai yang diharapkan.
\end{abstract}

Kata kunci : Laminated Veneer Lumber, sambungan balok kolom, kapasitas sambungan balok kolom

\section{PENDAHULUAN}

Pesatnya pertumbuhan penduduk di Indonesia menuntut meningkatnya kegiatan penyediaan perumahan. Penggunaan kayu sebagai bahan utama struktur dan juga bahan non struktural telah banyak kita kenal. Sebagai salah satu bahan struktural, kayu banyak dipilih karena ringan dan sederhana dalam proses pengerjaannya. Kayu bersifat renewable yaitu dijamin ketersediaannya sepanjang masa selama pengelolaan sumber dayanya dilakukan dengan lestari (Surjokusumo dkk, 2003).

Kayu sangat mudah ditemukan dari alam, proses pengolahan kayu untuk menjadi bahan struktural juga sangat mudah dan terjangkau menjadikan kayu sebagai bahan yang sangat diminati sehingga keberadaannya mulai terbatas. Kerusakan hutan akibat penbangan secara liar mulai banyak terlihat. Akibatnya untuk mendapatkan kayu dengan kualitas yang baik sangatlah sulit, jika ada kayu yang berkualitas baik pastilah harganya sangat mahal, karena untuk mendapatkan kualitas yang baik masa tanam pohon juga memerlukan waktu yang lama. 
Dalam hal ini maka para pelaku pembangunan harus mencari cara agar keberadaan kayu tetap terjaga di alam. Salah satunya adalah dengan pembuatan Laminated Veneer Lumber (LVL).

Laminated Veneer Lumber (LVL) kayu sengon merupakan kayu yang diproduksi dari kayu yang masa tumbuhnya singkat sehingga dapat terjamin ketersediaannya. Laminated Veneer Lumber (LVL) kayu sengon dibuat dengan cara merekatkan lembaran-lembaran kayu dengan menggunakan adhesive sehingga terbentuk kayu utuh. Kayu LVL mempunyai kekuatan yang setara dengan kayu konvensional sehingga layak digunakan sebagai material bangunan.

Pengembangan kayu olahan seperti Laminated Veneer Lumber (LVL) dengan bahan dasar kayu sengon ini memang sangat gencar dilakukan khususnya dalam pengembangan rumah praktis atau semacam backlog rumah yang memungkinkan dibangun dengan waktu singkat dan memanfaatkan kayu olahan dengan bahan dasar kayu yang memang dapat diproduksi dengan waktu yang singkat.

\section{METODE}

Metode yang digunakan dalam penelitian ini adalah metode eksperimental laboratorium dan analisis. Sebuah percobaan untuk mendapat suatu hasil yang menegaskan hubungan antara variabel - variabel yang diselidiki dilakukan dalam metode eksperimental.

Penelitian ini akan menyelidiki suatu percobaan berupa pengujian kekuatan hubungan balok kolom terhadap momen lentur kayu pada sambungan LVL kayu sengon. Bahan utama penelitian ini adalah kayu Laminated Veneer Lumber (LVL) dengan dimensi $18 \mathrm{~mm}$ x $80 \mathrm{~mm}$ x $500 \mathrm{~mm}$ dan $18 \mathrm{~mm}$ x $80 \mathrm{~mm}$ x $1000 \mathrm{~mm}$ yang telah dipilih permukaan yang halus, tidak mempunyai cacat fisik dan tidak mempunyai mata kayu dengan ukuran yang diisyaratkan.Benda uji berupa kolom persegi dan balok berbentuk III,dengan alat sambung baut. Pengujian dilakukan dengan cara menambahkan beban pada ujung balok secara bertahap untuk mengetahui lendutan yang terjadi pada ujung balok tersebut.

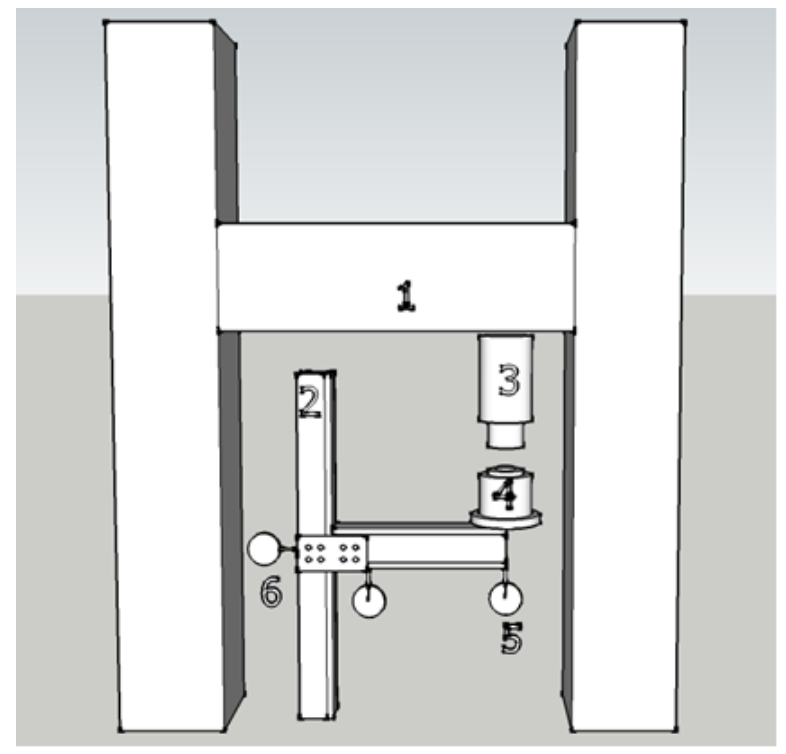

Gambar 1. Set Up Pengujian

1. Loading Frame

2. Benda Uji

3. Hidraulic jack

4. Load Cell

5. Dial Gange

6. Dial Gange 


\section{HASIL PENELITIAN DAN PEMBAHASAN}

\section{Hasil Pengujian Lendutan Ujung Balok}

Pengujian yang dilakukan di laboratorium bertujuan untuk mendapatkan data aktual mengenai beban maksimum yang dapat diterima, lendutan maksimum yang terjadi serta sudut rotasi sambungan balok kolom LVL. Berdasarkan pengujian yang dilakukan di Laboratorium Struktur Fakultas Teknik Universitas Sebelas Maret Surakarta, pengujian kapasitas sambungan balok kolom dilakukan dengan cara memberikan beban aksial pada balok secara bertahap sampai batas kemampuan benda uji dalam menerima beban tersebut. Batas kemampuan benda uji dalam menerima beban diindikasikan dengan kondisi retak atau patah pada sambungan antara balok dan kolom serta benda uji tidak mampu lagi menerima penambahan beban. Beban pada kondisi tersebut dianggap sebagai beban kritis dan lendutan yang terjadi dianggap sebagai lendutan maksimum.

Tabel 1 Beban dan Lendutan Maksimum Ujung Balok Sambungan LVL

\begin{tabular}{|c|c|c|c|c|c|}
\hline No & Benda Uji & $\begin{array}{c}\text { Beban Maks } \\
\text { (kg) }\end{array}$ & $\begin{array}{c}\text { Beban Rata- } \\
\text { rata }(\mathrm{kg})\end{array}$ & $\begin{array}{c}\text { Lendutan } \\
\text { Maks } \\
\text { diujung } \\
\text { balok (mm) }\end{array}$ & $\begin{array}{c}\text { Lendutan } \\
\text { Rata-rata } \\
(\mathrm{mm})\end{array}$ \\
\hline 1 & Sambungan I & 190 & & 126,55 & \\
\hline 2 & Sambungan II & 200 & 190 & 147,04 & 128,19 \\
\hline 3 & Sambungan III & 180 & & 110,99 & \\
\hline
\end{tabular}

\section{Perbandingan Antara Hasil Pengujian dengan Penelitian Sebelumnya}

Berdasarkan hasil pengujian yang dilakukan oleh Nia (2011) diperoleh grafik seperti pada Gambar 2. Akan tetapi dari data tersebut tidak semuanya bisa dijadikan acuan, karena setelah terjadi kerusakan kayu pada saat pembebanan dilakukan nilai penurunan bergantung pada kondisi pengujian, sehingga data yang digunakan adalah sebelum terjadi penurunan pembacaan beban pada load cell (ditandai dengan kotak merah pada grafik dibawah) dan diperjelas pada Gambar 3.

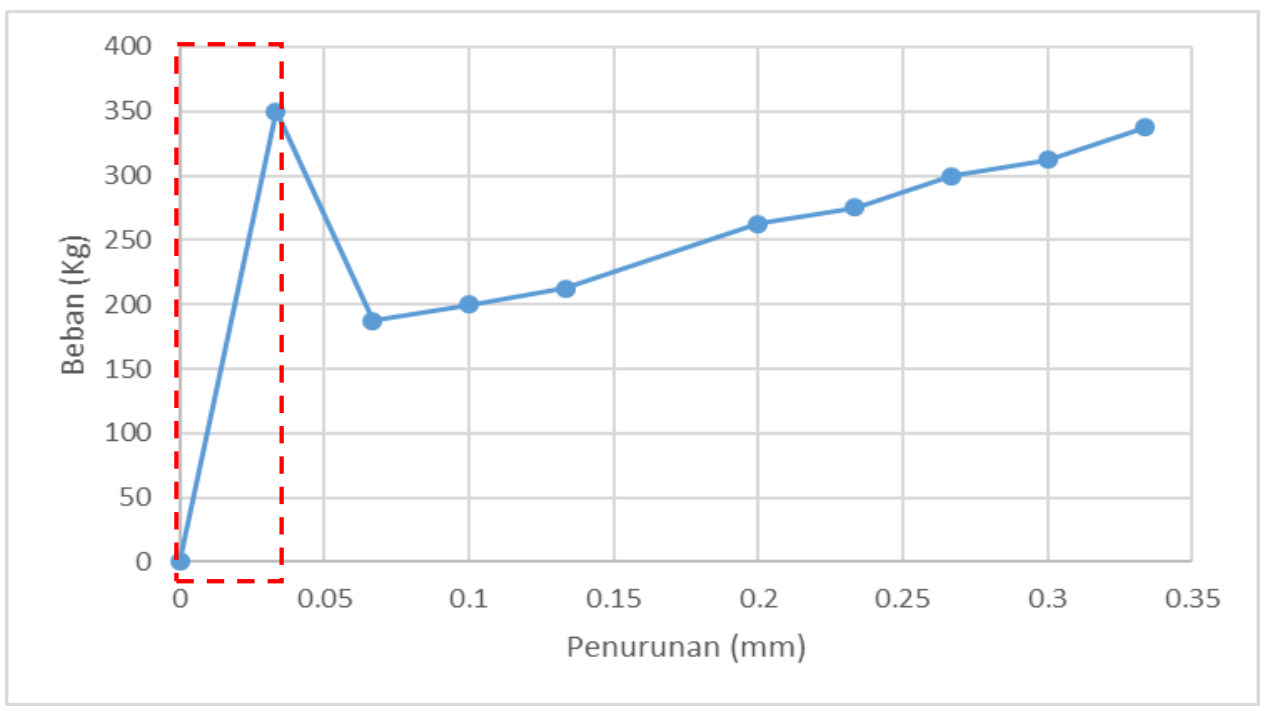


Gambar 1. Grafik Hubungan Penurunan dengan Beban

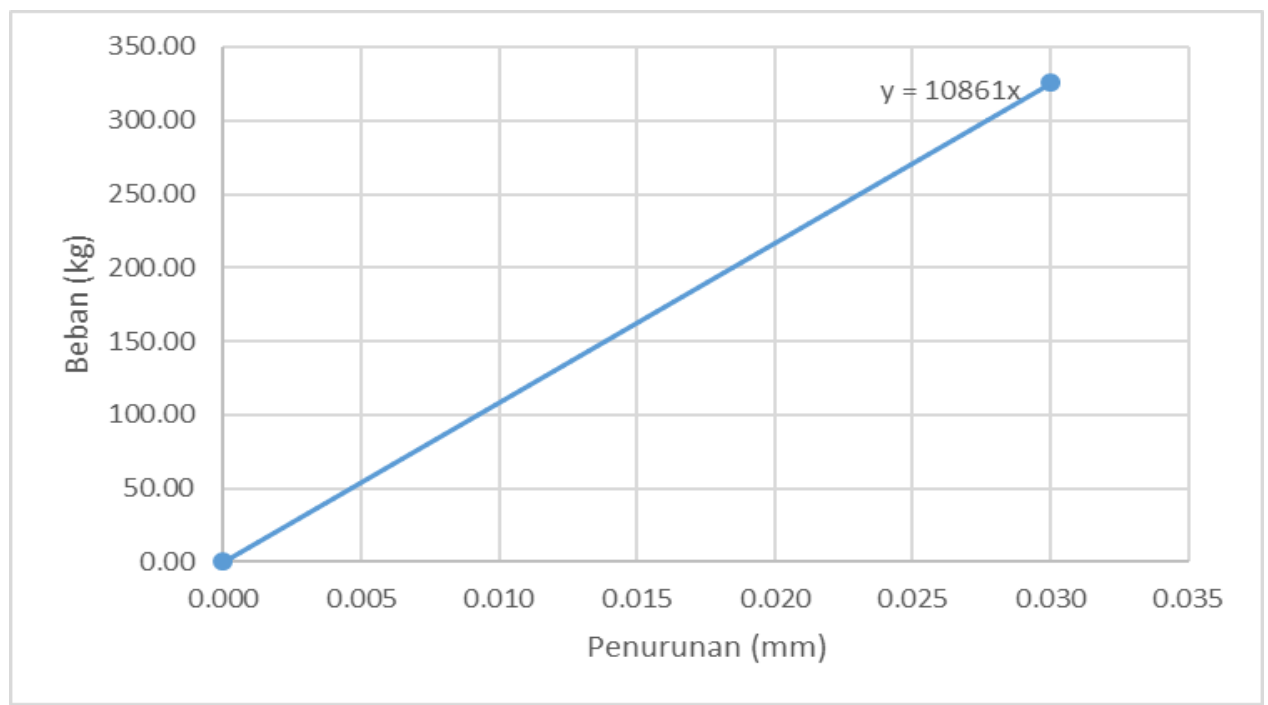

Gambar 3. Grafik Hubungan Penurunan dengan Beban

Selanjutnya perbandingan antara besar penurunan secara teori dan hasil pengujian yang dilakukan di laboratorium disajikan pada Tabel 2.

Tabel 2. Tabel hasil pengujian dan hasil perhitungan lendutan yang terjadi pada baut

\begin{tabular}{ccc}
\multirow{2}{*}{ Beban $(\mathrm{Kg})$} & \multicolumn{2}{c}{ Penurunan $(\mathrm{mm})$} \\
\cline { 2 - 3 } & Pengujian & Perhitungan \\
\hline 405.00 & 0.70 & 0.37 \\
\hline 427.50 & 1.29 & 0.39 \\
\hline 450.00 & 2.22 & 0.41 \\
\hline
\end{tabular}

Dari hasil diatas dapat dilihat bahwa nilai lendutan hasil pengujian lebih besar daripada hasil perhitungan yang mengacu pada penelitian Nia (2011).

Selanjutnya untuk mencari kapasitas sambungan adalah dengan cara membagi beban yang ada dengan luas permukaan LVL yang terkena beban.

\section{PEMBAHASAN}

Penelitian ini bertujuan untuk mengetahui seberapa besar kapasitas sambungan balok kolom LVL kayu sengon dengan hasil pengujian sampel I, II dan III berturut-turut adalah $18,9 \mathrm{~N} / \mathrm{mm}^{2}, 19,9 \mathrm{~N} / \mathrm{mm}^{2}$, dan $17,9 \mathrm{~N} / \mathrm{mm}^{2}$.

Dari data dan perhitungan diatas diperoleh hasil bahwa nilai kapasitas hasil pengujian lebih kecil daripada nilai hasil perhitungan yang mengacu pada penelitian Nia (2011). Hal ini disebabkan oleh :

a. Beban yang berada di ujung balok menimbulkan momen yang terjadi pada pangkal balok menjadi sangat besar, hal ini mengakibatkan beban yang bekerja pada baut juga menjadi sangat besar.

b. Lubang baut yang tidak presisi pada saat pembuatan sampel mengakibatkan perputaran sudut yang besar meskipun beban yang diterima ujung balok masih kecil dan kemungkinan belom mengakibatkan kerusakan pada kayu LVL. 
c. Pengujian yang dilakukan tidak dapat memenuhi syarat sebagai acuan untuk mencari kapasitas sambungan balok kolom dikarenakan sambungan yang ada bukan murni sambungan jepit seperti yang diharapkan, hal ini dibuktikan dengan adanya lendutan yang terjadi pada pangkal sambungan (dial 2).

Hasil pengujian menunujukkan lendutan yang terjadi pada sampel I, sampel II dan III masing-masing adalah $126,55 \mathrm{~mm}, 147,04 \mathrm{~mm}$, dan $110,99 \mathrm{~mm}$ sedangkan menurut perhitungan lendutan yang terjadi adalah $1,4982 \mathrm{~mm}, 1,5768 \mathrm{~mm}$, dan $1,4196 \mathrm{~mm}$.

\section{KESIMPULAN}

Kesimpulan yang dapat diambil dari hasil penelitian yang telah dilakukan adalah sebagai berikut:

a. Pengujian dilakukan dengan sampel kolom berbentuk III dan kolom berbentuk persegi.

b. Beban maksimal yang mampu ditahan oleh sampel sambungan balok kolom LVL kayu sengon yaitu sampel I, sampel II, dan Sampel III adalah 190, 200, dan $190 \mathrm{~kg}$.

c. Beban maksimal yang diterima oleh tiap baut pada balok sampel sambungan tersebut bertu rut turut adalah 427,5; 450; dan $405 \mathrm{~kg}$.

d. Beban maksimal yang diterima oleh tiap baut pada kolom sampel sambungan tersebut berturut-turut adalah 95, 100, dan $90 \mathrm{~kg}$.

e. Penurunan/lendutan yang terjadi pada tiap baut pada balok sampel sambungan tersebut berturutturut adalah 1,29; 2,22; dan 0,70 $\mathrm{mm}$.

Hasil didapat dari pengujian tidak dapat dijadikan sebagai acuan untuk mengetahui besar kapasitas sambungan balok kolom LVL.

\section{REKOMENDASI}

Beberapa saran yang berhubungan dengan pelaksanaan penelitian yang telah dilakukan yang mungkin dapat bermanfaat, antara lain:

a. Pada saat pembuatan sampel sebaiknya digunakan bor duduk dengan diameter mata bor sesuai dengan diameter baut agar lubang baut presisi.

b. Saat pengujian dilakukan sebaiknnya digunakan dial gauge digital agar pembacaan lendutan lebih teliti.

c. Perlu dilakukan penelitian lebih lanjut dengan kombinasi bentuk balok maupun kolom dengan bentuk lain.

\section{REFERENSI}

Akbar, Firdaus. 2012. Pengaruh Panjang Batang Terbadap Kuat Tekan Kolom Laminated Veneer Lumber (LVL) dari Bahan Kayu Sengon (Paraserianthes Falcataria L. Nielsen). Skripsi. Jurusan Teknik Sipil. Fakultas Teknik. Universitas Sebelas Maret. Surakarta.

Awaludin, Ali. 2005. Konstruksi Kayu. Biro Penerbit KMTS Jurusan Teknik Sipil Fakultas Teknik Universitas Gajah Mada. Yogyakarta.

Awaluddin, Ali. 2005. Perencanaan Sambungan Kayu. Biro Penerbit KMTS Jurusan Teknik Sipil Fakultas Teknik Universitas Gajah Mada. Yogyakarta.

Bakar, E.S. 1996. Kayu Laminasi Vinir Sejajar. Buletin Teknologi Hasil Hutan.

Dwi Handayani, Nia. 2011. Pengaruh Variasi Sudut Serat Pada Kuat Tumpu Kayu Laminated Veneer Lumber (LVL) Kayu Sengon. Skripsi. Jurusan Teknik Sipil Fakultas Teknik Universitas Sebelas Maret Surakarta.

Gere, J M dan Timoshenko, S. 2000. Mekanika Bahan, Edisi keempat, Erlangga, Jakarta.

Nurrahma Putri, Rismaya. 2014. Kapasitas Lentur Balok Laminated Veneer Lumber (LVL) Kayu Sengon. Skripsi. Jurusan Teknik Sipil Fakultas Teknik Universitas Sebelas Maret. Surakarta. 